\title{
Erratum to: An Online Evidence-Based Decision Support System for Distinguishing Benign from Malignant Vertebral Compression Fractures by Magnetic Resonance Imaging Feature Analysis
}

Kenneth C. Wang • Anthony Jeanmenne •

Griffin M. Weber • Shrey K. Thawait • John A. Carrino

Published online: 19 January 2011

(C) Society for Imaging Informatics in Medicine 2011

\section{Erratum to : J Digit Imaging}

DOI 10.1007/s10278-010-9316-3

A middle initial was inadvertently left off from an author, Thawait SK. The correct author list for this paper should be: Wang KC, Jeanmenne A, Weber GM, Thawait SK Carrino JA

The online version of the original article can be at http://dx.doi.org/ 10.1007/s10278-010-9316-3.

K. C. Wang $(\bowtie) \cdot$ S. K. Thawait $\cdot$ J. A. Carrino

Russell H. Morgan Department of Radiology and Radiological

Science, Johns Hopkins Hospital,

601 North Caroline Street, Room 5165,

Baltimore, MD 21287, USA

e-mail: kenwang@stanfordalumni.org

\section{A. Jeanmenne}

Department of Radiology,

Southern Illinois University School of Medicine,

Springfield, IL, USA

\section{G. M. Weber}

Department of Medicine, Beth Israel Deaconess Medical Center, Harvard Medical School,

Boston, MA, USA 